\title{
Use of Mannanoligosaccharides in Broiler Feeding
}

Author(s)

Flemming JS

Freitas JRS1

Fontoura P1

Montanhini Neto $\mathrm{R}^{2}$

Arruda JS

Post-Graduation Program on Food Technology ST/UFPR.

2 DVM - Cooperativa Agrícola Consolata Ltda (COPACOL).

\section{Mail Address}

José Sidney Flemming

Departamento de Zootecnia

Rua dos Funcionários, 1540

Bairro Cabral

80.035-050 - Curitiba, PR.

E-mail: flemmingjs@yahoo.com.br

\section{Keywords}

Broiler diets, alternative growth promoters, additives in broiler diets.

\section{Acknowledgements}

The authors thank Fundação de Amparo à Pesquisa do Estado de São Paulo (FAPESP) for financial support.

\section{ABSTRACT}

A study with 2,400 broilers was carried out to compare the effect of the use of mannanoligosaccharides, Saccharomyces cerevisiae cell wall or growth promoter (Olaquindox) in the diet on broiler. Diets were based on corn and soybean meal. A completely randomized experimental design was used, and the obtained data were evaluated by analysis of variance and test of Tukey at a level of $5 \%$. The following parameters were measured: feed intake, daily weight gain, feed conversion ratio, and mortality. It was concluded that the effect of the inclusion of mannanoligosaccharides in the diet on the studied parameters was significantly higher as compared to the inclusion of cell wall or to the control diet, but the effect was not different as compared to the inclusion of growth promoter.

\section{INTRODUCTION}

Prebiotics are products containing carbohydrates, which main component is mannose. These products are commonly use to reduce the colonization of the intestinal tract by enteropathogenic bacteria. Probiotics are mainly represented by mannanoligosaccharides (MOS) and fructo-oligosaccharides (FOS), present in the cell wall of yeasts, such as Saccharomyces cerevisiae. They exert their action by maintaining or reestablishing the conditions of eubiosis in the digestive tube, and thus, the normal microbial flora and the balance of the gastrointestinal tract (Santin et al., 2001).

These oligosaccharides are usually represented by the mannanoligosaccharides, and have the ability to bind to the fimbria of pathogenic bacteria, favoring the competitive exclusion by probiotics, as well as the population of the intestinal mucosa by eutropic microorganisms. Mannanoligosaccharide prebiotics can be used as substrate by bacteria, and some authors attribute increase in mineral retention and better bone mineralization in broilers fed these products (Bradley \& Savage, 1994). As eutropic bacteria and mannanoligosaccharides are added, balance conditions become permanent, preventing the establishment of Salmonella, E. coli, Clostridium, among others, and increasing the number of beneficial lactic-acid producing bacteria, thus maintaining eubiosis (Oyofo et al, 1999).

This study aimed at evaluating the live performance of broilers fed different diets containing different oligosaccharides and to compare them with growth promoters presently used in the poultry industry.

\section{MATERIAL AND METHODS}

The experiment was carried out in an experimental poultry house of Cooperativa Agricola Consolata Ltda (COPACOL), Brazil. A total number of 2,400 Ross commercial broilers, of both sexes, equally distributed 
into 24 pens (100 birds per pen), with wood shavings litter and equipped with feeders and drinkers. Broilers were submitted to four treatments (six replicates): (T1) control feed, no growth promoter; ( $T 2$ ) feed containing the antibiotic growth promoter (Olaquindox; $50 \mathrm{gr} / \mathrm{ton}$ ); (T3) feed containing mannanoligosaccharide (MOS, 500 $\mathrm{g} /$ ton ); and (T4) feed containing Saccharomyces cerevisiae cell wall (SCCW; 500 g/ton ) Birds and feed residues were weekly weighed to measure feed intake, daily weight gain, and feed conversion ratio. Mortality data were recorded daily. The experimental design used was randomized blocks. The experimental period was 1 to 42 days of age. The statistical analysis of data on weight, daily weight gain, feed intake, feed conversion ratio, and mortality was carried out using the software ESTAT 2.0 (1992); means were compared by the test of Tukey at a probability level of $5 \%$.

\section{RESULTS AND DISCUSSION}

Feed intake, daily weight gain and feed conversion ratio results during the different rearing stages are presented in Table 1. promoters, which also reduce pathogen colonization, thereby improving poultry performance (Miles et al, 1989).

Table 2 shows the data of the total experimental period. It is possible to observe that birds fed the SCCW diet presented lower feed intake as compared to those fed antibiotics. Daily weight gain was significantly higher in birds fed growth promoter (antibiotic) or MOS as compared to those fed the control diet and that containing SCCW. However, no significant differences were found in feed conversion ration or mortality among the treatments.

The best results presented by the birds fed MOS are probably due to an improvement of the integrity of the intestinal mucosa and reduction of the stress on the mucosa caused by the presence of mannanoligosaccharides, thereby increasing the absorption and utilization of the dietary nutrients (Crumplen et al, 1989; Bradley \& Savage, 1994).

Birds fed growth promoter presented higher feed intake and daily weight gain. We speculate that these results may be due to the elimination of undesirable microorganisms from the gastrointestinal tract. These

Table 1 - Feed intake (FI), daily weight gain (ADG), and feed conversion ratio (FCR) means of broilers during different production stages.

\begin{tabular}{|c|c|c|c|c|c|c|c|c|c|}
\hline & \multicolumn{3}{|c|}{1 to 10 days } & \multicolumn{3}{|c|}{1 to 28 days } & \multicolumn{3}{|c|}{1 to 42 days } \\
\hline & FI (g) & ADG (g) & FCR (g/g) & FI (g) & ADG (g) & FCR (g/g) & FI (g) & ADG (g) & $\overline{F C R ~(g / g)}$ \\
\hline Control & $593^{b}$ & $30^{a}$ & $1.37^{b}$ & $2048^{a}$ & $48^{a}$ & 1.55 & $4079^{a b}$ & $53.4^{a}$ & 1.82 \\
\hline Growth promoter & $603^{a}$ & $30^{a}$ & $1.38^{b}$ & $2048^{a}$ & $49^{a}$ & 1.48 & $4128^{a}$ & $56.1^{\mathrm{a}}$ & 1.75 \\
\hline MOS & $597^{a b}$ & $30^{a}$ & $1.39^{b}$ & $2033^{a}$ & $48^{a}$ & 1.50 & $4094^{\mathrm{ab}}$ & $55,0^{b}$ & 1.77 \\
\hline SCCW & $599^{a b}$ & $26^{b}$ & $1.55^{\mathrm{a}}$ & $1959^{b}$ & $45^{b}$ & 1.52 & $3980^{b}$ & $53,7^{b}$ & 1.77 \\
\hline
\end{tabular}

*Values within a column not followed by a common letter are significantly different by the test of Tukey $(p<0.05)$.

Birds fed with the diet containing MOS and the diet containing antibiotic showed higher feed intake during the different production stages. They also had higher daily weight gain during the stages 1-10 days of age and 1-28 days of age, which may be attributed to the higher feed intake. During the stage of 1-42 days of age, birds fed SCCW improved daily weight gain, reaching the same daily weight gain and feed conversion ratio as the birds fed MOS and antibiotics.

Gibson \& Roberfroid (1995), evaluating the use of indigestible carbohydrates, such as plant and yeast cell wall - classified as MOS complexes (glucomannanproteins, and particularly mannanoligosaccharides) - , found that carbohydrates can bind to the fimbria of bacteria, thus inhibiting the colonization of the gastrointestinal tract by pathogenic microorganisms. These findings are similar to those found with the use of growth
Tabela 2 - Feed intake (FI), daily weight gain (DWG), and feed conversion ratio (FCR) and mortality (MORT) means of 1 to 42days old broilers.

\begin{tabular}{lcccc} 
& FI (g) & ADG (g) & FCR (g/g) & MORT. (\%) \\
Control & $4079^{a b}$ & $53.4^{a}$ & 1.82 & 4.17 \\
Growth promoter & $4128^{a}$ & $56.1^{a}$ & 1.75 & 2.67 \\
MOS & $4094^{\text {ab }}$ & $55.0^{b}$ & 1.77 & 2.00 \\
SCCW & $3980^{b}$ & $53.7^{b}$ & 1.77 & 2.17 \\
\hline *Values within a column not followed by a common letter are \\
significantly different by the test of Tukey (p<0.05).
\end{tabular}

microorganisms decrease nutrient absorption, increase the rate of passage of the digesta, and interfere with intestinal cell wall turnover rate and the thickness of the intestinal mucosa (Visek,1978; Miles et al, 1989).

Table 3 shows the evolution of average weights (in grams) of the birds in the different treatments during 
the experimental period. No significant differences were found between the results from broilers fed MOS or antibiotic. When MOS-fed birds were compared to those SCCW-fed, it is observed that MOS produced better results. The control treatment, with no addition of any product, presented the worst results.

The conditions for the establishment of desirable microorganisms and their replication promoted by oligosaccharides are described by Gibson \& Roberfroid (1995) in an extensive study with plant and yeast cell walls containing high concentrations of mannanoligosaccharides.

Table 3 - Evolution of mean weights (in grams), according to treatments, during the experimental period.

\begin{tabular}{|c|c|c|c|c|}
\hline & $\begin{array}{l}\text { Initial } \\
\text { weight }\end{array}$ & $\begin{array}{l}\text { Weight } \\
\text { at } 14 \text { days }\end{array}$ & $\begin{array}{l}\text { Weight } \\
\text { at } 28 \text { days }\end{array}$ & $\begin{array}{l}\text { Weight } \\
1 \text { to } 42 \text { dias }\end{array}$ \\
\hline Control & 43.0 & $432^{a}$ & $1351^{a}$ & $2288^{b}$ \\
\hline Growth promoter & 43.2 & $436^{a}$ & $1377^{a}$ & $2398^{a b}$ \\
\hline MOS & 43.0 & $428^{a}$ & $1349^{a}$ & $2353^{a}$ \\
\hline SCCW & 42.6 & $386^{b}$ & $1286^{b}$ & $2297^{b}$ \\
\hline
\end{tabular}

Table 4 - Experimental diets using during the experiment $(\mathrm{kg} /$ ton).

\begin{tabular}{|c|c|c|c|}
\hline Ingredients & $\begin{array}{l}\text { Starter } \\
1 \text { at } 14 \text { days }\end{array}$ & $\begin{array}{l}\text { Growning } \\
15 \text { at } 28 \text { days }\end{array}$ & $\begin{array}{c}\text { Finisher } \\
29 \text { at } 42 \text { days }\end{array}$ \\
\hline Yellow corn & 595,0 & 647,0 & 684,5 \\
\hline Soybean meal (45\% & CP) 310,0 & 237,0 & 203,0 \\
\hline Meat meal $(47 \% C P)$ & 27,0 & 34,0 & 50,0 \\
\hline Poultry by product m & neal 20,0 & 40,0 & 25,0 \\
\hline Poultry, fat & 25,0 & 25,0 & 25,0 \\
\hline Common salt & 3,0 & 3,0 & 3,0 \\
\hline Limestone ground & 7,0 & 5,0 & 2,5 \\
\hline Calcium phosphate & 6,0 & 2,0 & - \\
\hline $\begin{array}{l}\text { Vitamin, mineral, } \\
\text { aminoacids, aditives } \\
\text { premix }^{1}\end{array}$ & 7,0 & 7,0 & 7,0 \\
\hline $\begin{array}{l}\text { Calculated } \\
\text { analysis }\end{array}$ & $\begin{array}{c}\text { Starter } \\
1 \text { at } 14 \text { days }\end{array}$ & $\begin{array}{l}\text { Growning } \\
15 \text { at } 28 \text { days }\end{array}$ & $\begin{array}{c}\text { Finisher } \\
29 \text { at } 42 \text { days }\end{array}$ \\
\hline Crude protein \% & 21,8 & 20,7 & 19,0 \\
\hline $\begin{array}{l}\text { Metabolizable Energ) } \\
(\mathrm{cal} / \mathrm{kg})\end{array}$ & 3020 & 3100 & 3150 \\
\hline Lisyne digest \% & 1,18 & 1,13 & 0,97 \\
\hline Methionine \% & 0,50 & 0,40 & 0,35 \\
\hline Calcium \% & 0,97 & 0,90 & 0,90 \\
\hline Phosphorus avall \% & 0,43 & 0,42 & 0,42 \\
\hline \multicolumn{4}{|c|}{$\begin{array}{l}1 \text { - premix levels: vitamins: vit.A } 8.000 \mathrm{UI} \text {, vit D3 } 2.000 \mathrm{UI} \text {, vit.E } 15 \mathrm{UI} \text {, } \\
\text { tiamin } 2 \mathrm{mg} \text {, riboflavin } 5 \mathrm{mg} \text {, niacin } 30 \mathrm{mg} \text {, pantotenic acid } 12 \mathrm{mg} \text {, } \\
\text { piridoxin, biotin } 50 \mathrm{mcg} \text {, fólic ácid } 0,5 \mathrm{mg} \text {, cianocobalamin } 20 \mathrm{mcg} \text {, } \\
\text { colin } 500 \mathrm{mg} \text {. minerals: manganese } 70 \mathrm{mg} \text {, iron } 80 \mathrm{mg} \text {, cupper } 10 \\
\mathrm{mg} \text {, zinc } 70 \mathrm{mg} \text {, selenium } 0,3 \mathrm{mg} \text { iodine } 1 \mathrm{mg} \text {, cobalt } 0,2 \mathrm{mg} \text {. Adittives: } \\
\text { lisyne starter } 0,20 \% \text {, growning } 0,15 \% \text {, finisher } 0.10 \% \text {; methionine - } \\
\text { starter } 0,30 \% \text {, growning } 0,25 \% \text {, finisher } 018 \% \text {. }\end{array}$} \\
\hline
\end{tabular}

\section{CONCLUSIONS}

Taking into consideration the conditions under which this experiment was carried out, it is possible to conclude that:

- The inclusion of growth promoter (antibiotic) produced the same results as the inclusion of mannanoligosaccharide in the diet.

- The use of mannanoligosaccharide produced significantly better results as compared to the use of yeast cell wall.

- The non-inclusion of growth promoters or of mannanoligosaccharides in broiler diets may cause production losses.

\section{REFERENCES}

Bradley GT, Savage TF. Enhance utilization of dietary calcium, phosphorus, nitrogen and metabolizable energy in poults feed diet containing a yeast culture. Poultry Science 1994; 73 (Supplement):124.

Crumplen R, D'Amore T, Panchal CJ, Stwart CG. Industrial uses of yeast: Present and future. Yeast 1989; 5 (special issue):3-9.

ESTAT 2.0 Sistema de análise estatística. Jaboticabal(SP): Polo Computacional - Departamento de Ciências Exatas: UNESP; 1992.

Gibson GR, Roberfroid MB. Dietary modulation of the human colonic microbiota: introducing the concept of probiotics. Journal of Nutrition 1995; 125:1401-1412.

Miles RD, Janky DM, Woodward AS, Harms RH, Butcher G, Henry PR. Antibiotic effects on broiler performance. Intestinal tract strength and morfology. Gainesville (FL): University of Florida. Departament of Animal Science; 1989.

Oyofo BA, Deloach JR, Corrier DE, Norman JO, Ziprin RL, Mollenhauer $\mathrm{HH}$. Prevention of Salmonella thifphimurium colonization of broilers with D-mannose. Poultry Science 1989; 68:1357-1360.

Santin E, Maiorka A, Macari M, Grecco M, Sanchez JC, Okada TM, Myasaka AM. Performance and intestinal mucosa development of broiler chickens fed diets containing Sacharomyces cerevisae cell wall. Journal of Applied Poultry Research 2001; 10:236-244.

Visek WJ. The mode of growth promotion by antibiotics. 1978 Journal of Animal Science. 1978; 46 (Supplement):1447. 